International Journal of Applied Economics, Finance and Accounting

ISSN 2577-767X

Vol. 3, No. 1, pp. 10-14

2018

DOI: $10.33094 / 8.2017 .2018 .31 .10 .14$

(C) 2018 by the authors; licensee Online Academic Press, USA

\title{
Theoretical Framework and Analysis of New Bankruptcy Regulations in Saudi Arabia
}

Rehana Parveen ${ }^{1}$

Emna Chikhaoui

\begin{abstract}
This research reviews the regulations of bankruptcy system in Saudi Arabia in the light of the advanced international practices in this field, in order to identify best practices and adopt them in accordance with Shari'a and regulations and in conformity with commercial customs to apply these regulations in the Kingdom of Saudi Arabia. The aim of this step is to identify the general regulations of the new system, its philosophy and its main characteristics by conducting a general study of the legal frameworks governing bankruptcy in order to identify the most prominent features of these systems and their general policies and procedures. The aim of this research is to identify options for developing and explaining the detailed rules and approaches for each of the main policies and features agreed upon according to bankruptcy regulations in Saudi Arabia.
\end{abstract}

Keywords:

Regulations

System

Policies

Procedures

Practices

Rules

Conformity.

JEL Classification:

G33; K22;K35;K4;K49.

\section{Introduction}

The research seeks to establish a regulatory environment that will contribute to expanding the base of private investment projects in terms of number and size by preserving the economic value that they add to the macroeconomic. In order to achieve this, the system will give priority to the procedures of reconciliation of the debtor, The research will adopt a number of mechanisms to increase the chances of success of these procedures, including the principle of suspending applications by which any creditor is prohibited from taking any action against the debtor outside the framework of the procedures to be provided for in the bankruptcy regulations in Saudi Arabia (Mortgages). This principle is intended to prevent any person from disrupting the debtor's access to an agreement with his creditors. The newly approved bankruptcy regulation will also give the judiciary the possibility of forcing creditors to plan the debtors (troubled) to deal with their debts, From the use of the "option to terminate the contract", whenever their sole bond was to disrupt the debtor's condition or to enter into bankruptcy (Balleisen, 2001).

In terms of the belief in the importance of preserving the rights of creditors and contractors because of their significant role in contributing to the expansion of the base of investment projects, the draft system will differentiate between debtors who have a real and realistic opportunity to return their activity and achieve added value to the economy and help them to pay their obligations with respect to their creditors and between debtors whose activity is not expected to return to a level that satisfies the creditors' expectations of payment of their obligations. In the latter case, the draft system will give priority to liquidation proceedings on other proceedings to establish assets of the debtor whose activity is not expected to return to the desired level to improve management, and to achieve this, the draft rules of mechanisms to ensure complete liquidation regularly and rapidly adopt (DePamphilis, 2009).

In view of the fact that debtors are expected to return to their normal level with a number of rights, the most important of which is suspending applications and the possibility of eliminating creditors from debtprocessing schemes and preventing their contractors from using the "option to terminate the contract", this may be a disincentive to creditors' and the adoption of a number of mechanisms to ensure a balance between the rights of creditors and the rights of debtors in this regard, including the establishment of restrictions and exceptions to the principle of suspension of applications in accordance with the details below, from obliging 
the opposing creditors as well as the requirement of fairness of the debt-processing plans and their rationality, as well as respecting the priority order of the debt and giving priority to the rights of the contractors who were prevented from exercising their right to terminate the contract as a result of the insolvency or bankruptcy of the debtor. The importance of these systems is to be understood by the Ministry of Finance. The law of bankruptcy will include a number of provisions that take into account the nature of these establishments and encourage entrepreneurs to start their work. These provisions include simplified procedures for dealing with these establishments in addition to some detailed provisions that help stimulate the private sector to finance these facilities (Mańko, 2013).

This is in line with the World Bank's (2015) which states that most advanced bankruptcy systems involve a set of provisions aimed at maintaining the sustainability of economically viable enterprises that have the ability to survive and are efficient at the same time operations. This is otherwise the case for projects that are financially distressed and lack operational efficiency and sustainability. Bankruptcies are liquidated, and their assets placed in the hands of those who manage them better. According to the World Bank report, bankruptcy regimes have achieved the desired goal, particularly the support of the national economy and the access of private investment projects to finance if they achieve either of two things: (Sandage \& Tammann, 2006). (1) Return the debtor's activity to its normal level as soon as possible. (2) Raising the debt repayment ratio.

\section{Objectives of Bankruptcy Regulations in Saudi Arabia}

Since the current applied legislations in Saudi Arabia are not sufficiently governing the procedural and judicial aspects of bankruptcy matters. The new Bankruptcy Law will further reduce the financial difficulties on bankrupt or distressed debtors by encouraging them to fulfil their obligations, reorganize their financials in order to continue their business operations aiming to support and develop the economy. Under current legislation there is no easy way to wind up the activities of indebted companies in Saudi Arabia and the new law could help with government plans to restructure the economy and make it more attractive to outside investors. In addition, it will protect the creditors' rights, reduce the costs and timeframe of the bankruptcy procedures and most importantly encourage small and medium businesses to invest in the commercial market. The main objective of the Bankruptcy Law is to implement detailed provisions related to the Liquidation, Settlement and Financial Reorganization. This law consisting 231 clauses distributed over 17 chapters, it aims to organize the procedures of bankruptcy.

\section{Scope of New Bankruptcy Regulations in Saudi Arabia}

The provisions of the Bankruptcy Law will be applied on any (Clyde co.):

- Natural person practicing commercial, professional and/or profitable activities in KSA;

- KSA registered commercial and professional companies and any other businesses aiming to generate profits on the KSA territory ; and

- Natural and/or juristic foreign investors (non KSA nationals) owning assets or practicing commercial, professional and/or profitable activities in KSA through a licensed entity. The Bankruptcy Law shall apply only to the foreign investor's assets existing in the KSA,

\section{Regulations of Bankruptcy Proceedings in Saudi Arabia}

Saudi Arabia recently published a new Bankruptcy Law. This is the biggest latest development of a string of reforms under Vision 2030 as part of efforts to attract foreign investment and encourage private sector activity, to further encourage the participation of foreign and domestic investors by structuring the business legal framework. The new law will come in to effect from $18^{\text {th }}$ August 2018. This article mainly provides a general analysis of the new bankruptcy law and its implications for businesses operating in the Kingdom.

The new system aims to regulate bankruptcy procedures:

1. Protective settlement.

2. Financial reorganization.

3. Liquidation.

4. Preventive settlement of small debtors.

5. Financial reorganization of small debtors.

6. Liquidation of small debtors.

7. Administrative liquidation.

\subsection{New Financing}

The debtor's entry into the reconciliation or reorganization stage will make it difficult to obtain new financing, which is an important element for the success of the conciliation or reorganization, as it ensures the debtor's continuing operations. The draft regulations will therefore include provisions to facilitate the debtor's access to new financing during the reconciliation phase Organization. These provisions include the use of new financing as a priority over unsecured and non-performing debt, taking into account the secured debt created prior to commencement of conciliation or reorganization proceedings as well as excellent debt. The draft law 
will provide protection for new financing contracts from pre-liquidation procedures, liquidation of the company. In any event, any new financing must be certified in the conciliation or reorganization phase (Balleisen, 2001).

\subsection{Continuity of Contracts}

Support from the draft regime for the continuity of the debtor's operations would be to prevent any contractor to use the "contract dissolution option", which includes contracts relating to the debtor's operational operations, and the right of the debtor to determine which contracts will continue and contracts which will be extinguished. In order to safeguard the rights of these contractors, the draft system would consider that their rights from such contracts would be costs for the reconciliation or reorganization phase, which would be given high priority by the project (Jones, 2007).

\subsection{Claims of the Debtor}

Where the debtor has claims against third parties, it shall, in cases where the debtor is dismissed from the administration, have to initiate proceedings for the claim of the debtor's rights with third parties, and the competent court shall be the competent jurisdiction, unless such claims as a result of or closely related to bankruptcy proceedings (such as cases in which the bankruptcy trustee seeks to invalidate bankruptcy protection actions), the competent jurisdiction of the bankruptcy court has jurisdiction (DePamphilis, 2009).

\subsection{Claims of the Creditors}

The regulations will suspend claims during the liquidation period (in cases where conciliation or reorganization or procedures cannot be implemented), giving it a greater opportunity to deal with such claims and try to resolve them during liquidation. In cases where it cannot be resolved during the liquidation phase, the claim is referred to the competent judicial authority (Jones, 2007).

- Approval of the termination of the period of suspension of claims (either with the permission of the debtor or the bankruptcy trustee or the bankruptcy court).

- Failure to implement the final judgment of the competent judiciary in the ordinary form but is considered a debt in the process of bankruptcy and subject to implementation to oversee the bankruptcy.

\subsection{Commencement of the Proceedings}

In view of the multiplicity of procedures to be provided by the regulations and the divergence of their provisions and objectives, the requirements for taking advantage of such procedures and the conditions for their commencement differ depending on the nature of the procedure itself. Since the use of such procedures does not require that the debtor be insolvent and since the debtor is always seeking to benefit from these procedures, the draft statute will not establish a specific standard for the definition of bankruptcy to benefit from conciliation or reorganization proceedings. These two procedures can therefore be invoked regardless of whether the debtor is technically bankrupt. However, the debtor will be required to provide proof of the need to initiate either of the two procedures, such as being bankrupt, likely to be bankrupt or financially precarious. In the event of a request for an amicable settlement, such a request could be supported by a specialized thirdparty statement indicating that there was a reasonable chance of reaching a settlement with the creditors (Mańko, 2013).

The regulations will follow clear and easy procedures to demonstrate that the debtor is bankrupt in accordance with the cash flow standard and therefore the possibility of liquidating its assets. In the absence of a clear and specific test with respect to the phase of conciliation and reorganization and an incentive for the debtor to apply for the proceedings of the conciliation or reorganization phase. To achieve this, the draft system will use the non-fulfillment of the executive instrument as a tool to prove that the cash flow criterion has been met with a deadline for the debtor to be implemented. This is a draft system to address legislative and application deficiencies, for example in the current Commercial Court system which mixes the financial flows test with the balance sheet test; It was established that local applications were difficult to subject to liquidation in Saudi Arabia, since the judiciary required the debtor to explicitly admit bankruptcy or to issue a final judgment. In fact, the procedures are not clear in the event of a final judgment. Is it necessary to implement the judicial debt before the enforcement judges in an attempt that is not usually successful? What is the evidence that the legal debt is a commercial religion? (Sandage \& Tammann, 2006).

\section{Procedures for Reorganizing Small Bankruptcies}

The provisions of this procedure shall be similar to the provisions of the amicable settlement procedure for small delicts, and shall differ from the following: (Bermant, 1999) 1. The task of managing the day-to-day work of the debtor shall be entrusted to the trustee of the bankruptcy (including the submission of proposals for debt treatment) and shall be appointed by the court or the debtor itself after notifying the court as creditors retain their right to challenge the appointment of the trustee. The suspension of claims includes 
requests for the implementation of safeguards. 2. If the plan does not obtain the approval of the majority of creditors (two-thirds), the Secretary of the bankruptcy will liquidate.

\section{Liquidation Procedures for Small Debtors}

The use of this procedure shall be based on a request submitted to the Court in accordance with a form prepared for that purpose. The Secretary of the Tribunal shall act in the absence of judicial guidance, and it is not necessary to hold meetings with creditors here. If the debtor is a natural person, it shall be rehabilitated 12 months after the commencement of the proceedings (Braucher, 1993).

\section{Assets without Value and Administrative Liquidation}

In the event that its assets are non-existent, the debtor shall provide a specific statement of assets and liabilities to the judiciary in which it undertakes the validity of what is stated therein. This statement may be dealt with by the bankruptcy committee. This committee reviews the formalities and arranges the liquidation of the activity. If the debtor is a natural person, it is automatically considered 12 months after the commencement date of the proceedings, if the bankruptcy is not due to default or fraud, and the bankruptcy committee also investigates any misconduct by the debtor and decides whether action Or initiation of noneligibility procedures) where appropriate.

\section{Recovery of Funds}

The new system contains substantive provisions allowing the Court to scrutinize past transactions that occurred during a specified recovery period, provided that this period is appropriate (to be determined not to exceed two years) for the distinction between real transactions and those intended to conceal the debtor's assets And damage to creditors, in preparation for the second cancellation and the liability of the parties to the transaction, knowing that the parties that have the relationship with the debtor will have the burden of proving that the transactions that took place during the recovery period are real transactions. For natural persons, the recovery period will be longer, due to the higher risk of concealing funds. These provisions will ensure investor confidence in injecting more investment into private enterprises (Staten et al., 1993).

\section{Practical Considerations}

1. A number of practical issues and assistance will be taken into account in the formulation of the new regime to enhance its transparency and predictability, including a consistent approach to its formulation in the form of comprehensive and accessible legislation that makes it possible to benefit from it.

2. It is proposed to establish a publicly available financial inquiry system and a bankruptcy register to enhance the continuity and participation of creditors.

3. The development of a strategy to raise awareness about aspects of reorganization to benefit from the procedures provided by the new system may contribute to encouraging the community to accept and act on such procedures.

4. Further studies should be undertaken to support the implementation of the new system and to identify changes to judicial systems and the necessary adjustments to legal and judicial training curricula.

5. Moreover, the idea of establishing a bankruptcy committee should be considered and the system reviews regularly reviewed, the list of trustees established and the procedures for their designation as last resort, the administrative liquidation of assets of low or no value, Fraudulent practices, and restrictions on them to assume any administrative functions when required under a segregation regime.

\section{Conclusion}

The bankruptcy system regulates the funds and takes into account the rights of creditors when institutions and companies find absolute transparency that helps to liquidate assets after maximizing their value to sell at higher prices to provide a financial balance between the interests of investors and the rights of creditors under strict regulatory conditions. By reducing the length of their accreditation and providing them with easy procedures, thus increasing the efficiency of their exploitation of opportunities and reducing their costs. The bankruptcy regulations in Saudi Arabia provided detailed provisions on preventive settlement, financial reorganization and liquidation procedures, and considered granting the first two actions a priority aimed at removing debtors and enabling them to resume their commercial and economic activities as soon as possible while at the same time raising their debt repayment. In order to support projects of economic feasibility when exposed to a financial bump without prejudice to the rights of their creditors. The project did not overlook the distinction between economically viable projects and projects that do not wish to achieve such feasibility. Although the system allows the bankrupt debtor to resume its activity, it takes into account the rights of its creditors fairly, to enhance confidence in the credit market and financial transactions. In 
addition, the system encourages troubled enterprises to reorganize their finances and correct their situation to reach an amicable settlement with their creditors that preserves their rights and enables them to return to their economic activity.

\section{References}

Balleisen, E. J. (2001). Navigating failure: Bankruptcy and commercial society in antebellum America: Univ of North Carolina Press.

Bermant, G. (1999). Bankruptcy by the numbers-one hand clapping: What we know, and still need to know, about consumer cases. American Bankruptcy Institute Journal, 18(2), 30-31.

Braucher, J. (1993). Lawyers and consumer bankruptcy: One code, many cultures. American Bankruptcy Law Journal, 67, 501.

DePamphilis, D. M. (2009). Mergers, acquisitions, and other restructurings (5th ed., pp. 299-302): Elsevier, Academic Press.

Jones, Y. D. (2007). Bankruptcy reform: Value of credit counseling requirement is not clear (GAO-O7-203). Washington, D.C.: Government Accountability Office.

Mańko, R. (2013). Survival of the socialist legal tradition? A polish perspective. Comparative Law Review, 4.

Sandage, A., \& Tammann, G. A. (2006). Absolute magnitude calibrations of population I and II Cepheids and other pulsating variables in the instability strip of the Hertzsprung-Russell diagram. Annual Review of Astronomy and Astrophysics, 44, 93-140.

Staten, M. A., Kohrt, W. M., Kirwan, J. P., Bourey, R. E., King, D. S., \& Holloszy, J. O. (1993). Insulin resistance in aging is related to abdominal obesity. Diabetes, 42(2), 273-281.

World Bank's. (2015). Principles for effective insolvency and creditor/debtor regimes (pp. 6). 